\title{
RONALD DWORKIN'S JUSTICE FOR HEDGEHOGS AND PARTNERSHIP CONCEPTION OF DEMOCRACY (WITH A COMMENT TO JEREMY WALDRON'S "A MAJORITY IN THE LIFEBOAT")
}

\author{
Imer B. FLORES
}

\section{Resumen:}

En este artículo el autor se enfoca principalmente en la última parte de Justice for Hedgehogs (Justicia para erizos), de Ronald Dworkin y en su argumento a favor de la concepción asociativa o societaria de democracia. Para tal propósito, primero, recuerda algunas de las características centrales que Dworkin ha adelantado en obras anteriores, pero intrínsecamente relacionadas, acerca de moralidad politica, la igualdad y la democracia; segundo, reevalúa los argumentos a favor de la concepción asociativa o societaria de democracia; tercero, reconsidera la resistencia producida por Jeremy Waldron en su "A Majority in the Lifeboat" ("Una mayoria en el bote salvavidas"), y la respuesta ofrecida por Dworkin, pero toda vez que puede parecer insuficiente, trata de presentar una respuesta alternativa -o complementaria - para responder al reto de Waldron. Finalmente insiste en la importancia de tomar a Ronald Dworkin seriamente.

Palabras clave:

Democracia, concepción mayoritaria, concepción societaria, gobierno/regla de mayoria. 
Abstract:

In this article the author focuses mainly in the last part of Ronald Dworkin's Justice for Hedgehogs and in his argument for a partnership conception of democracy. For that purpose, first, he recalls some of the main features that Dworkin had advanced in previous but intrinsically related works, about political morality, equality and democracy; second, he reassess the arguments for a partnership conception of democracy; third, he reconsiders the resistance produced by Jeremy Waldron in his "A Majority in the Lifeboat" and the response provided by Dworkin, but since it may appear insufficient, he intends to present an alternative -or complementary - riposte in order to meet Waldron's challenge; and, finally, he insists in the importance of taking Ronald Dworkin seriously.

Keywords:

Democracy, Majoritarian Conception, Partnership Conception, Majority Rule. 
The fox knows many things, but the hedgehog knows one big thing. ARCHILOCHUS

Value is one big thing. The truth about living well and being good and what is wonderful is not only coherent but mutually supporting: what we think about any one of these must stand up, eventually, to any argument we find compelling about the rest.

Ronald DWORKIN

Summary: I. Introduction: Dworkin's Justice for Hedgehogs. II. Political Morality, Equality and Democracy. III. Dworkin's Partnership Conception of Democracy. IV. Comment to Jeremy Waldron's "A Majority in the Lifeboat". V. Conclusion: Taking Ronald Dworkin Seriously.

\section{INTRODUCTION: DwORKIN'S JUSTICE FOR HEDGEHOGS}

Taking Ronald Dworkin and his Justice for Hedgehogs ${ }^{1}$ seriously implies taking "value seriously".2 This is the one big thing that Dworkin, i.e. the self-proclaimed hedgehog of our time, knows and is willing to defend from "several foxy causes", such as "value skepticism", "value pluralism" and "value conflict". ${ }^{3}$ On the contrary, by defending the large and old philosophical thesis of "the unity of value", 4 he ar-

1 Vid. Dworkin, Ronald, Justice for Hedgehogs, Cambridge, Massachusetts, Harvard University Press, 2011. Vid. also "Symposium Justice for Hedgehogs: A Conference on Ronald Dworkin's Forthcoming Book", Boston University Law Review, Vol. 90, No. 2, April, 2010, pp. 465-1086.

2 Dworkin, Justice for Hedgehogs, supra note 1, p. 17.

3 Ibidem, pp. 7-11.

4 Ibidem, p. 1. I will like to suggest that the "unity of value" thesis in Dworkin's thought can be traced all the way back to the early publication of "The Model of 
gues -as he has been arguing for more than forty years and to different extents - for the integration of "ethical and moral values", "personal and political morality", and "law and morality". 5

In the different parts of the book, Dworkin presents arguments: for truth about value and against various forms of skepticism ("Part I: Independence");6 for conceptual interpretation and against collaborative or explanatory interpretation ("Part II: Interpretation");7 for a morality of self-affir-

Rules I" in 1967 and has remained ever since throughout his works. There are at least two grounds for such claim: 1) the weight dimension of principles; and 2) the interconnection of principles. Vid. Dworkin, Ronald, Taking Rights Seriously, Taking Rights Seriously, 2nd ed., Cambridge, Massachusetts, Harvard University Press, 1978. (Originally published: 1977.) (There is Spanish version: Los derechos en serio, trans. Marta Guastavino, Barcelona, Ariel, 1984.) Ibidem, pp. 26 and 41: "[principles] have a dimension that rules do not - the dimension of weight or importance" and "principles rather hang together than link together [as rules do]".

5 Dworkin, Justice for Hedgehogs, supra note 1, pp. 1-19. On the integration of law and morality: Vid. Dworkin, Ronald, "Introduction: Law and Morals", in Justice in Robes, Cambridge, Massachusetts, Harvard University Press, 2006, pp. 1-35. (There is Spanish version: La justicia con toga, trans. Marisa Iglesias Vila e Íñigo Ortiz de Urbina Gimeno, Madrid, Marcial Pons, 2007.) Ibidem, pp. 34-35: "we might treat law not as separate from but as a department of morality. We understand political theory that way: as part of morality more generally understood but distinguished, with its own substance, because applicable to do distinct institutional structures. We might treat legal theory as a special part of political morality distinguished by a further refinement of institutional structures."

6 Dworkin, Justice for Hedgehogs, supra note 1, pp. 21-96. It is worth to mention that "Part I: Independence" was labeled in the previous versions of the manuscript as "Part I: Objectivity" and as "Part I: Truth". Both concepts are closely related to his previous work, vid. Dworkin, Ronald, "Objectivity and Truth: You'd Better Believe It", Philosophy \& Public Affairs, No. 25, 1996, pp. 87-139." On objectivity and skepticism: Vid. also Dworkin, Ronald, A Matter of Principle, Cambridge, Massachusetts, Harvard University Press, 1986, pp. 171-174 and 175-177.

7 Dworkin, Justice for Hedgehogs, supra note 1, pp. 97-188. Dworkin's "conceptual interpretation" can be traced all the way back to his "interpretive attitude" and "interpretive concepts", which appear for first time in Law's Empire: Vid. Dworkin, Ronald, Law's Empire, Cambridge, Massachusetts, Harvard University Press, 1986, pp. 47 and 49. (There is Spanish version: El imperio de la justicia: de la teoria general del derecho, de las decisiones e interpretaciones de los jueces y de la integridad politica y legal como clave de la teoría y práctica, trans. Claudia Ferrari, Barcelona, Gedisa, 1992.) But which have their roots in A Matter of Principle, where he not only recharacterized "legal argument and analysis as interpretive in character" and "law as interpretation" but also referred to "interpretive arguments" and "interpretive judgments": Vid. Dworkin, A Matter of Principle, supra note 6 , pp. 3-4, 117-177, and 171 . 
mation and against a morality of self-abnegation, by developing accounts of the indispensable conditions of living well, such as (human) dignity that includes two principles: self-respect and authenticity, 8 along as a defense of free will and responsibility, ${ }^{9}$ as well as for a substantive morality concerning duty, harm and obligation, including associative and political obligations ("Part III: Ethics" \& "Part IV: Morality"); 10 finally, for a partnership conception of democracy and against a majoritarian conception of democracy, by reviewing his arguments about political morality, including political, legal and human rights, and revising his interpretive conceptions of liberty, equality and democracy; and, last but certainly not least, by revisiting the relationship between law and morals ("Part V: Politics"). ${ }^{11}$

In my commentary, I intend to focus mainly in the last part of Justice for Hedgehogs and in the core argument for a partnership conception of democracy. For that purpose, following this opening Section I, we will: recall, in Section II, some of the main features that Dworkin had advanced in previous but intrinsically related works, about political morality, equality and democracy; reassess, in Section III, his arguments for a partnership conception of democracy; reconsider, in Section IV, the resistance produced by Jeremy Waldron in his "A Majority in the Lifeboat" and the response provided by Dworkin, but since it may appear insuf-

8 Dworkin, Justice for Hedgehogs, supra note 1, pp. 189-218. The two principles were introduced early on: vid. ibidem, p. 2: "No government is legitimate unless it subscribes to two reigning principles. First, it must show equal concern for the fate of every person over whom it claims dominion. Second, it must respect fully the responsibility and right of each person to decide for himself how to make something valuable of his life." And, defined later on: vid. ibid., pp. 203-204: "The first is a principle of self-respect. Each person must take his own life seriously: he must accept that it is a matter of importance that his life be a successful performance rather than a wasted opportunity. The second is a principle of authenticity. Each person has a special, personal responsibility for identifying what counts as success in his own life; he has a personal responsibility to create that life through a coherent narrative or style that he himself endorses."

9 Ibidem, pp. 219-252.

10 Ibidem, pp. 189-252 \& 253-324.

11 Ibidem, pp. 325-423. 
ficient we will try to present an alternative - or complementary - riposte in order to meet Waldron's challenge; and, finally, in the closing Section $\mathrm{V}$, we will insist in the importance of taking Ronald Dworkin seriously.

\section{Political Morality, Equality and Democracy}

Let me start this part by bringing to mind that more than three lustrums ago the book Life's Dominion. An Argument about Abortion, Euthanasia, and Individual Freedom ${ }^{12}$ was available; two lustrums ago, the book Sovereign Virtue. Theory and Practice of Equality was in print; 13 and one lustrum ago, the Scribner Lectures at Princeton University were delivered and, one year later, published in a book titled Is Democracy Possible Here? Principles for a New Political Debate; ${ }^{14}$ and, finally, his long awaited and already world famous Justice for Hedgehogs is due to appear early in 2011. This information is relevant, since Dworkin at the beginning of "Part V: Politics", the last but certainly not the least of equally important parts of his forthcoming book, advances that since "I have written a good deal about political morality, particularly in my books Life's Dominion, Sovereign Virtue, and Is Democracy Possible Here?... I ask readers

12 Vid. Dworkin, Ronald, Life's Dominion. An Argument about Abortion, Euthanasia, and Individual Freedom, New York, Alfred A. Knopf, 1993. (There is another edition: New York, Vintage Books, 1994.) (There is Spanish version: El dominio de la vida. Una discusión acerca del aborto, la eutanasia y la libertad individual, trans. Ricardo Caracciolo \& Victor Ferreres, Barcelona, Ariel, 1998.)

13 Vid. Dworkin, Ronald, Sovereign Virtue. The Theory and Practice of Equality, Cambridge, Massachusetts, Harvard University Press, 2010. (There is Spanish version: Virtud soberana. La teoria y la práctica de la igualdad, trans. Fernando Aguiar González \& María Julia Bertomeu, Madrid, Paidós, 2003; and a book review of mine: Flores, Imer B., "Ronald Dworkin, Sovereign Virtue. The Theory and Practice of Equality", in Cuestiones Constitucionales. Revista Mexicana de Derecho Constitucional, No. 3, julio-diciembre 2000, pp. 283-291.)

14 Dworkin, Ronald, Is Democracy Possible Here? Principles for a New Political Debate, Princeton, Princeton University Press, 2006. (There is Spanish version: La democracia posible. Principios para un nuevo debate politico, trans. Ernest Weikert García, Barcelona, Paidós, 2008.) 
to treat those books as incorporated into this one by reference". 15

On the one hand, Dworkin advances in the first three chapters of Sovereign Virtue the "idea of equality" beginning in a principle, i.e. "the abstract egalitarian principle", which "stipulates that government must act to make the lives of citizens better, and must act with equal concern for the life of each member." 16 In Chapter 4 "Political Equality" he explores the relationship between democracy and equality, by addressing the question: "What form of democracy is most appropriate to an egalitarian society?"17 For that purpose, he introduces a crucial distinction between two different approaches: 18

The first approach offers... a dependent interpretation or conception of democracy, because it supposes that the best form of democracy is whatever form is most likely to produce the substantive decisions and results that treat all members of the community with equal concern. On that view, the main features of a democracy - near-universal suffrage, free speech, and the rest- are justified because a community in which the vote is widely held and speech is free is more likely to distribute material resources and other opportunities and values in an egalitarian way. So it recommends, when controversial cases arise about the best detailed form of democracy, that a consequentialist test be used: Which decision of these controversial issues seems most conducive to advancing or protecting these substantive egalitarian goals? The second approach produces... a detached interpretation or conception of democracy. It insists that we judge the fairness or democratic character of a political process by looking to features of that process alone, asking only whether it distributes political power in an equal way, not

15 Dworkin, Justice for Hedgehogs, supra note 1, p. 328. Since in this section I am interested in the relationship between democracy, equality and political morality, in my remarks I will focus only in the last two books.

16 Dworkin, Sovereign Virtue, supra note 13, p. 184.

17 Ibidem, p. 185.

18 Ibidem, p. 186. 
what results it promises to produce... So it argues that freedom of speech, as well as widespread suffrage, helps to make political power more equal. And it argues, when controversial questions of detail arise about our political process, that these should be resolved by asking which decision is best calculated to improve equality of political power still further.

The former "supplies an input test: democracy is essentially a matter of equal distribution of power over political decisions" and the latter "supplies an output test: democracy is essentially a set of devices for producing results of the right sort." 19 In spite of the popularity of the detached conception, Dworkin argues that it cannot be successful in a pure form and outlines a pure dependent conception, which provides the most attractive choice. He later proceeds to illustrate and to test that conception by considering the important political controversy: "is judicial review undemocratic?"20 In a few words, judicial review does not damage the participatory values of democracy, including the agency goals by allowing "people to participate not merely as voters but as moral agents" 21 and concludes: ${ }^{22}$

On the contrary, it guards those goals, [i.e. agency goals,] by giving special protection to freedom of speech and to the other liberties that nourish moral agency in politics. It does more: it provides a forum of politics in which citizens may participate, argumentatively, if they wish, and therefore in a manner more directly connected to their moral lives than voting almost ever is. In this forum, moreover, the leverage of the minorities who have the most negligible leverage in ordinary politics is vastly improved.

19 Idem.

20 Ibidem, p. 190.

21 Ibidem, p. 187.

22 Ibidem, p. 209. 
Furthermore, in Chapter 10 "Free Speech, Politics, and the Dimensions of Democracy" he recalls that "Democracy... means government by the people" but it can be understood in two radically different ways: On one side, for the "majoritarian conception" it "means government by the largest number of the people. On this majoritiarian view, the democratic ideal lies in a match between political decision and the will of the majority or plurality of opinion."23 On the other, for the "partnership conception" it "means government by all the people, acting together as full and equal partners in a collective enterprise of self-government." 24

23 Ibid., p. 357.

24 Ibid., p. 358. Ronald Dworkin originally characterized the "partnership conception" as "constitutional conception". Cfr. Dworkin, Ronald, "Introduction: The Moral Reading and the Majoritarian Premise", Freedom's Law. The Moral Reading of the American Constitution, Cambridge, Massachusetts, Harvard University Press, 1996, pp. 1-38. (There is Spanish version: "La lectura moral y la premisa mayoritaria", trans. Imer B. Flores, in Cuestiones Constitucionales. Revista Mexicana de Derecho Constitucional, No. 7, julio-diciembre, 2002, pp. 3-52.) Ibid., p. 17 (p. 25): "If we reject the majoritarian premise, we need a different, better account of the value and point of democracy... which I call the constitutional conception of democracy...It denies that it is a defining goal of democracy that collective decisions always or normally be those that a majority or plurality of citizens would favor if fully informed and rational. It takes the defining aim of democracy to be a different one: that collective decisions be made by political institutions whose structure, composition, and practices treat all members of the community, as individuals, with equal concern and respect. This alternate account of the aim of democracy, it is true, demands much the same structure of government as the majoritarian premise does. It requires that day-to-day political decisions be made by officials who have been chosen in popular elections. But the constitutional conception requires these majoritarian procedures out of a concern for the equal status of citizens, and not out of any commitment to the goals of majority rule. So it offers no reason why some nonmajoritarian procedure should not be employed on special occasions when this would better protect or enhance the equal status that it declares to be the essence of democracy, and it does not accept that these exceptions are a cause of moral regret. / The constitutional conception of democracy, in short, takes the following attitude to majoritarian government. Democracy means government subject to conditions... of equal status for all citizens. When majoritarian institutions provide and respect the democratic conditions, then the verdicts of these institutions should be accepted by everyone for that reason. But when they do not, or when their provision or respect is defective, there can be no objection, in the name of democracy, to other procedures that protect and respect them better." 
Dworkin notes one fundamental and relevant difference between the majoritarian and partnership conceptions of democracy: 25

Citizens play two main roles in a mature democracy. They are, first, the judges of political contests whose verdicts, expressed in formal elections or in referenda or other forms of direct legislation, are normally decisive... Citizens are also, however, participants in the political contests they judge: they are candidates and supporters whose actions help, in different ways, to shape public opinion and to fix how the rest of the citizens vote. The majoritarian conception of democracy pays exclusive attention to the first of these roles... The partnership conception recognizes both roles, because it supposes that in a true democracy citizens must play a part, as equal partners in a collective enterprise, in shaping as well as constituting the public's opinion.

On the other hand, Dworkin begins Is Democracy Possible Here? by acknowledging an increasing polarization between the two dominant cultures in the United States of America, whom disagree about almost everything including the scope of their disagreements: "American politics are in an appalling state. We disagree, fiercely, about almost everything. We disagree about terror and security, social justice, religion in politics, who is fit to be a judge, and what democracy is. There are not civil disagreements: each side has no respect for the other. We are no longer partners in self-government; our politics are rather a form of war." 26

And even by adding up the implications of considering the other as a form of enemy and this as a kind of war:27

If the two-cultures view is right, the lack of argument in American politics is understandable and inevitable. The split between the two cultures would be an unbridgeable gulf sep-

25 Dworkin, Sovereign Virtue, supra note 13, p. 358.

26 Dworkin, Is Democracy Possible Here?..., supra note 14, p. 1.

27 Ibidem, p. 6. 
arating the comprehensive and wholly clashing worldviews of two Americas. If that is so -if the division between the two cultures is not just deep but bottomless - then there is no common ground to be found and no genuine argument to be had. Politics can only be the kind of war it has become. Many students of our politics think that that is our situation, and they may be right. But that would be alarming and tragic. Democracy can be healthy with no serious political argument if there is nevertheless a broad consensus about what is to be done. It can be healthy even if there is no consensus if it does have a culture of argument. But it cannot remain healthy with deep and bitter divisions and no real argument, because it then becomes only a tyranny of numbers.

Is the depressing diagnosis right? Is there really no common ground to be found between the trenches of two hostile political armies? Is no real argument possible?

What's more, he advances his agenda: although he considers that the diagnosis is chiefly right, it is still possible to reconcile the two hostile political armies and to have a real argument, if they can commit to find some shared principles. In Dworkin's voice: ${ }^{28}$

I shall argue... that in spite of the popular opinion I just described, we actually can find shared principles of sufficient substance to make a national political debate possible and profitable. These are very abstract, indeed philosophical, principles about the value and the central responsibilities of a human life. I suppose not that every American would immediately accept these principles, but that enough Americans on both sides of the supposedly unbridgeable divide would accept them if they took sufficient care to understand them.

Additionally, by accentuating that in his alternative, instead of considering useless to debate, it is necessary to re- 
invigorate the argumentative dimension of politics and as a consequence it is useful to deliberate and discuss: 29

Most people on each side of the division now seem persuaded that it is useless to try to argue with or even to understand the other side... I hope to persuade enough people that this popular opinion is wrong - that it is profitable to study our most heated political controversies at a more philosophical level - to help begin a process that might later reinvigorate the argumentative dimension of our politics.

\section{DWORKIN'S PARTNERSHIP CONCEPTION OF DEMOCRACY}

In order to review Dworkin's Justice for Hedgehogs and his take on democracy, partnership and majority rule, it is necessary, briefly, to revisit: first, the concept of democracy; second, the two conceptions of democracy; third, the four characterizations of polarization and contrast them to the previous two conceptions of democracy; and, fourth, the partnership conception of democracy itself.

\section{The Concept of Democracy}

According to its etymology - demos (people) and kratos (government, power or rule) - 'democracy' means "government, power or rule of the people". It is prima facie a form of government in contraposition to other forms of government. The classical typology includes not only three pure forms: 1) "autocracy" (better known as "monarchy") as the government of one -i.e. the monarch; 2) "aristocracy" as the government of few-i.e. the "best-ones"; and 3) "democracy" as the government of all -i.e. the people. ${ }^{30}$ But also three im-

29 Ibidem, p. 8.

30 Hans Kelsen did criticize the traditional classification and its trichotomy, and distinguished between two types of constitutions: democracy and autocracy. Vid. Kelsen, Hans, General Theory of Law and State, trans. Anders Wedberg, Cambridge, Massachusetts, Harvard University Press, 1945, p. 284: "Democracy means that the "will" which is represented in the legal order of the State is identical 
pure or corrupt forms: 1) "tyranny" as the government of one -i.e. the tyrant; 2) "oligarchy" as the government of few -i.e. the "better-off" or rich; and 3) "demagogy" as the government of many (on behalf of all) -i.e. the "worse-off" or poor (also characterized as the mob).

It is worth to note that Aristotle considered "democracy" pejoratively, an equivalent to the term "demagogy", as one vicious extreme in contraposition to "oligarchy" as the other vicious extreme, whereas his politeia was the virtuous middle term by comprising the government of the middle class and as such of both the poor and the rich, i.e. of both the many and the few. ${ }^{31}$ Let me explain that I will reserve "demagogy" for the impure or corrupt form and "democracy" for the pure or true one and will assume that the latter is the government of all the people: not only of both the poor and the rich but also of both the many and the few (or alternatively of both the majority and the minority).

The problem is that for some authors "democracy" seems to be reduced to the government of the many or of the majority in detriment of the few or of the minority, a so-called "majoritarian conception of democracy". On the contrary, an authentic or true "democracy" and democratic government must be neither of poor or rich, nor of many or few, nor of majority or minority, but of all: both of poor and rich, both of many and few, both of majority and minority, what Dworkin labels as "partnership conception of democracy". ${ }^{32}$

So far the notion of "democracy" as a form of government and the typology has served to emphasize the ownership - or partnership - "of" the political or sovereign power, depending on whether it corresponds to one, few, many, or all. Nevertheless, the exercise of this political or sovereign (legitimate) power not only must be done directly and indi-

with the wills of the subjects. Its opposite is the bondage of autocracy. There the subjects are excluded from the creation of the legal order, and harmony between the order and their wills is in no way guaranteed."

31 Aristotle, The Politics, New York, Cambridge University Press, 1988, IV, 11, 1295b, pp. 97-98.

32 Vid. supra note 24. 
rectly "by" its (legitimate) owners - or partners - and their (legitimate) representatives, but also must be done "for" them and their (legitimate) benefit, not in their (illegitimate) detriment. The three ideas already sketched can be put together into an integral definition of democracy, such as the one embodied in Abraham Lincoln's maxim and in the Fifth French Republic's motto: "government of the people, by the people, and for the people".33

In that sense, an authentic or true "democracy" must be the government of, by and for all the people: poor and rich, many and few... men and women, heterosexuals and homosexuals, believers and non-believers... majority and minority, and so on. Hence, "democracy" is "government of all the people, by all the people - directly on their own ("direct democracy") or indirectly through their representatives ("representative democracy") — and for all the people". ${ }^{34}$

33 Vid. Lincoln, Abraham, "The Gettysbury Address, November 19, 1863, in Lincoln on Democracy, New York, Harper Collins, 1990, p. 308: "government of the people, by the people, for the people". (The emphasis is added.) Vid. also Article 2 (6) of the French Fifth Republic Constitution: "Its principle is government of the people, by the people and for the people." (The emphasis is added.) Cfr. Dworkin, Justice for Hedgehogs, supra note 1, p. 379 (warning that in democracy talk: "We are soon knee-deep in slogans. Only democracy can provide dignity. Government must be of the people, by the people and for the people. The people must govern themselves. Each citizen must be offered an equal and meaningful role. One person must have one vote and no one more than one vote...").

34 Vid. Flores, Imer B., "Heráclito vis-à-vis Parménides: Cambio y permanencia como la principal función del derecho en una democracia incipiente", in Molina Piñeiro, Luis J. et al. (eds.), Funciones del derecho en las democracias incipientes. El caso de México, México, Porrúa and Facultad de Derecho, UNAM, 2005, pp. 154-157; "Actores, procesos e instituciones democráticas: Hacia una verdadera democracia en México", in Molina Piñeiro, Luis J. et al. (eds.), Instituciones, Actores y Procesos Democráticos en México 2007, México, Porrúa and Facultad de Derecho, UNAM, 2008, pp. 314-319; “¿Es posible la democracia en México?”, in Molina Piñeiro, Luis J. et al. (eds.), ¿Polarización en las expectativas democráticas de México 2008-2009? Presidencialismo, Congreso de la Unión, órganos electorales, pluripartidismo y liderazgo, México, Porrúa, Facultad de Derecho-UNAM, Instituto de Derechos Humanos "Bartolomé de las Casas"-Universidad Carlos III de Madrid y COPUEX, 2009, pp. 471-495; "Sobre los triunfos del proceso democratizador en México: A propósito del movimiento anulacionista y del voto nulo", in Molina Piñeiro, Luis J. et al. (eds.), Balance en el proceso democratizador de México 19882009, México, Porrúa, Facultad de Derecho-UNAM, Instituto de Derechos Humanos "Bartolomé de las Casas"-Universidad Carlos III de Madrid y COPUEX, 2009, pp. 744-764; and "Democracia y polarización: ¿(in)compatibilidad?", in Díaz 


\section{Two Conceptions of Democracy}

However, since the concept of democracy is an interpretive and much contested one, ${ }^{35}$ there are at least two competing and conflicting conceptions of democracy, i.e. the majoritarian and the partnership, which attempt to answer the question: "Who are the people?" As far as I know this distinction can be traced all the way back to John Stuart Mill, who - almost one-hundred and fifty years ago- in his Considerations on Representative Government, in 1861, under the epigraph "Of True and False Democracy: Representation of All, and Representation of the Majority Only", indicated: 36

Two very different ideas are usually confounded under the name democracy. The pure idea of democracy, according to its definition, is the government of the whole people by the whole people, equally represented. Democracy as commonly conceived and hitherto practiced is the government of the whole people by a mere majority of the people, exclusively represented. The former is synonymous with the equality of all citizens; the latter, strangely confounded with it, is a government of privilege, in favor of the numerical majority, who alone possess practically any voice in the State. This is the inevitable consequence of the manner in which the votes are now taken, to the complete disfranchisement of minorities.

Müller, Luis T. (ed.), V Jornadas: Crisis y derechos humanos, México, Instituto de Investigaciones Juridicas, UNAM, 2010, pp. 97-116.

35 Dworkin, Justice for Hedgehogs, supra note 1, p. 379.

36 Mill, John Stuart, Considerations on Representative Government, Indianapolis, The Liberal Arts Press, 1958, pp. 102-103. (There is Spanish version: Consideraciones sobre el gobierno representativo, trans. Antonio Guzmán Balboa, México, Herrero Hermanos, 1966, pp. 120-121). 
In Dworkin's perspective, at the present time, the two competing conceptions of democracy not only coexist but also are still in conflict: 37

The two views of democracy that are in contest are these. According to the majoritarian view, democracy is government by majority will, that is, in accordance with the will of the greatest number of people, expressed in elections with universal or near universal suffrage. There is no guarantee that a majority will decide fairly; its decisions may be unfair to minorities whose interests the majority systematically ignores. If so, then the democracy is unjust but no less democratic for that reason. According to the rival partnership view of democracy, however, democracy means that the people govern themselves each as a full partner in a collective political enterprise so that a majority's decisions are democratic only when certain further conditions are met that protect the status and interests of each citizen as a full partner in that enterprise. On the partnership view, a community that steadily ignores the interests of some minority or other group is just for that reason not democratic even though it elects officials by impeccably majoritarian means. This is only a very sketchy account of the partnership conception, however. If we find the more familiar majoritarian conception unsatisfactory, we shall have to develop the partnership view in more detail.

Actually, as he acknowledges, the United States of America is neither a pure example of the majoritarian conception of democracy nor of the non-majoritarian (or partnership) one. Although the bipartisan system and the majority principle reinforce the former, since the founding fathers lim-

37 Dworkin, Is Democracy Possible Here?..., supra note 14, p. 131. Vid. Waluchow, W. J., A Common Law Theory of Judicial Review. The Living Tree, Cambridge, Cambridge University Press, 2007, pp. 106-109. Vid. also Flores, Imer B., "The Living Tree: Fixity and Flexibility. A General Theory of (Judicial Review in a) Constitutional Democracy?", Problema. Anuario de Filosofia y Teoría del Derecho, No. 2, 2008, pp. 285-305; and Flores, Imer B., "The Living Tree Constitutionalism: Fixity and Flexibility", Problema. Anuario de Filosofía y Teoría del Derecho, No. 3, 2009, pp. 37-74. 
ited the power of the majorities in various forms, by including anti-majoritarian devices, which were latter reinforced by other institutions, such as the filibuster and the judicial review (of the constitutionality) of the acts of the other (elected) branches of government, it can be said that they also supported the latter. ${ }^{38}$

On one side, a minority of either thirty-four or forty-one (out of the one-hundred senators) can block the majority of bringing a decision to a final vote, depending on whether it is a substantive or procedural issue. And, on the other, the power of the political majorities is limited by the recognition of individual constitutional rights that legislative majorities cannot infringe and much less step over. Aside, Dworkin alerts that the degraded state of the public debate endangers the partnership conception of democracy and strengthens the majoritarian one, including viewing the other as an enemy and politics as a war: 39

If we aim to be a partnership democracy... the degraded state of our political argument does count as a serious defect in our democracy because mutual attention and respect are the essence of partnership. We do not treat someone with whom we disagree as a partner - we treat him as an enemy or at best as an obstacle- when we make no effort either to understand the force of his contrary views or to develop our own opinions in a way that makes them responsive to his. The partnership model so described seems unattainable now because it is difficult to see how Americans on rival sides of the supposed culture wars could come to treat each other with that mutual respect and attention.

38 Vid. Dworkin, Is Democracy Possible Here?..., supra note 14, pp. 135 and 137. In fact, the existence of the Senate was designed to divide the most dangerous branch of government and to give stability to the government by protecting the minorities against a speedy and unreflected legislative majority in the House of Representatives.

39 Ibidem, pp. 132-133. 


\section{Four Characterizations of Polarization}

Since the term 'polarization' is ambiguous and as such considered either as an activity-process or product-result (of such activity-process) we must stipulate our use of them, accordingly we are going to reserve the verb 'polarize' to the activity-process and 'polarization' for the product-result. On one side, 'polarize' means to "cause division of opinion: to make the differences between groups or ideas ever more clear-cut and extreme, hardening the opposition between them, or become ever more clear-cut and extreme in this way." On the other, 'polarization' means "concentration, as of groups, forces, or interests, about two conflicting or contrasting positions" and of which a rational conciliation seems highly or near to impossible (for example, between those for and against: abortion, death penalty, euthanasia, same-sex marriage, and so on). By the same token, the polarization describes the formation of antagonistic (social) classes or groups and its confrontation (verbi gratia: bourgeois-proletariat, capitalist-socialists, conservative-liberal, democrat-republican, left-right, moderate-radical, poor-rich, rural-urban, and so on).

Anyway, we can distinguish between two great options regarding polarization: (1) exclusion of one group by the other or (2) inclusion of one group by the other. Similarly, each option can be further divided into two theses: one strong and other weak. On one side, in case of exclusion: (A) the strong version is characterized by the elimination or suppression of the "different", especially if "dissident", which is considered as an "enemy", i.e. ethnic cleansing or mass deportation, and may lead to an "authoritarian or totalitarian imposition-restoration"; and (B) the weak version is depicted by the division, excision, fragmentation, secession, or separation into two or more parts, which are not willing to cooperate, i.e. balkanization for short, and may lead to a "libertarian emancipation". On the other, in case of inclusion: $(\mathrm{C})$ the strong version is illustrated by the agi- 
tation, convulsion, or tension between majorities-minorities and may lead to a "mayoritarian -or minoritariantyrannization"; 40 and (D) the weak version is portrayed by the deliberation, discussion, participation or representation of all partners and may lead to a (pure or true) "democratic association".

From the preceding lines, it is possible to derive four different characterizations of 'polarization': two of which are openly incompatible with any conception of democracy -(A) and (B); and, two of which are presumably compatible with democracy: one with the majoritarian conception (C); and, other with the partnership conception (D). Since there is not much of democratic in (A) and (B), we will analyze only the two versions presumably compatible with democracy in the search for the one that is purely or truly so. In (C) polarization is recognized not only as the oppression of $\mathrm{mi}$ norities by majorities but also as the opposition of minorities against majorities to the extent that it is coherent with the majoritarian conception. On the contrary, in (D) polarization is renowned as the association between both majorities and minorities to the extent that it is consistent with the partnership conception.

Nowadays, we tend to attribute to polarization a negative connotation, but democracy has not necessarily a positive one, keep in mind Winston Churchill's speech where he characterized democracy as a "lesser evil" in the continuum: "Many forms of government have been tried, and will be tried in this world of sin and woe. No one pretends that democracy is perfect or all-wise. Indeed, it has been said that democracy is the worst form of government except all

40 Elsewhere we have characterized these different situations as "majoritycracy", i.e. "government of the majority"; and, as "minoritycracy" (i.e. "government of the minority"); and even as "partycracy", i.e. "government of political parties"). Vid. Flores, "Heráclito vis-à-vis Parménides...", supra note 34, p. 159; and Flores, "Actores, procesos e instituciones democráticas...", supra note 34, pp. 338-339. 
those other forms that have been tried from time to time". ${ }^{41}$ Let me elucidate, I am trying to suggest that it may be the case that at least one form of polarization is a "lesser evil" for democracy than other tendencies, including those of "non-polarization". Therefore, following Dworkin, I not only conceive polarization as an opportunity for democracy and not necessarily as the problem in itself but also perceive that the partnership conception of democracy is better suited than the majoritarian one to deal with polarization, since the former (D) by facing polarization ends up decreasing or reducing it, while the latter (C) either by avoiding or confronting polarization winds up increasing or even multiplying it, and what's more - and worse - may lead to (A) and/or (B). ${ }^{42}$

\section{The Partnership Conception of Democracy}

First and foremost, Dworkin is adamant in his critique of "a supposedly neutral account of democracy: democracy is government according to the will of the majority expressed in reasonably frequent elections with nearly full suffrage af-

41 Vid. Churchill, Winston, "Parliament Bill. Speech on the House of Commons, November 11, 1947", The Oxford Dictionary of Quotations, 3a. ed., Oxford, Oxford University Press, 1979, p. 150.

42 To illustrate how the majoritarian conception may lead either to the elimination and suppression of the "different", especially if "dissident", which is considered as an "enemy", or to the division, excision, fragmentation, secession, and separation into two or more parts, which are not willing to cooperate, I will like to point, following Linda C. McClain, to Muriel Barbery's The Elegance of the Hedgehog best seller novel: Vid., Barbery, Muriel, The Elegance of the Hedgehog, trans. Alison Henderson, New York, Europa Editions, 2008. (Original title and publication: L'élegance du hérison, Paris, Gallimard, 2006.) Vid., for example, on the one hand, ibid., p. 84: "life is a permanent battle where you can only win be destroying the other guy... A world where there's room for other people is a dangerous world." And, on the other hand, ibid., p. 32: "Politics... A toy for little rich kids that they won't let anyone else play with." I am grateful to Linda C. McClain not only for pointing out some of the parallelisms between Barbery's and Dworkin's books but also for recommending the novel to me. Vid. McClain, Linda, "Justice and Elegance for Hedgehogs - In Life, Law, and Literature", in "Symposium...", supra note 1, pp. 863-902. 
ter political debate with free speech and a free press." 43 Furthermore, he challenges whether: "Is democracy, understood as majority rule, something valuable in itself?" And even questions: "Why should the fact that numerically more people favor one course of action over another signal that the more favored policy is either fairer or better?". ${ }^{44}$

To prove his point, i.e. majority rule is not intrinsically fair in all circumstances, Dworkin recognizes "We might say: when people locked in a joint enterprise disagree about what should be done, the only fair solution is to count heads. But that must be rejected as a universal default principle of fair play: it is not automatically true." 45 For that purpose, he reintroduces a "hoary philosophical example":46

When a lifeboat is overcrowded and one passenger must go overboard to save the rest, majority vote would seem close to the worst method of choosing the victim. Personal attachments and antagonisms would play a role they should not play, and so a lottery would be much superior. Those attachments and antagonisms spoil politics as well, but on a much larger scale, and this makes the idea that majority vote is intrinsically or automatically fair in that context seem at least dubious.

\section{And in slightly different terms: ${ }^{47}$}

43 Dworkin, Justice for Hedgehogs, supra note 1, pp. 347-348.

44 Ibidem, p. 348.

45 Idem.

46 Idem. Dworkin introduces the example in Is Democracy Possible Here?..., supra note 14, p. 139: "Suppose passengers are trapped in a lifeboat on the high seas that will sink unless one person - any person-jumps or is thrown overboard. How shall the group decide who is to be sacrificed? It seems perfectly fair to draw straws or in some other way to let fate decide. That gives each person the same chances of staying alive. Letting the group vote, however, seems a very bad idea because kinship, friendships, enmities, jealousies, and other forces that should not make a difference will then be decisive. We use lotteries to make some fateful political decisions as well. When we draft soldiers, we do not hold referendums on who should be drafted. We choose by lot. Perhaps we should make more use of chance in politics. The Athenians selected their leaders by lot, and it is not vividly clear that the quality of our legislators would decline if we chose them in the same way."

47 Dworkin, Justice for Hedgehogs, supra note 1, p. 387. 
[W] hen a lifeboat is overcrowded and one passenger must be thrown over else all will die, it would not be fair to hold a vote so that the least popular among them would be drowned. It would be much fairer to draw lots.

Dworkin reinforces his point with a rhetorical question that is quite revealing: "But if democracy means majority rule, and majority rule is not something desirable in itself, then why should we care so much to protect our democracy?". ${ }^{48}$ In a nutshell, his main claim is that majority rule - which is closely tied to democracy as its criteria - is not necessarily intrinsically fair or valuable, ${ }^{49}$ but democracy is and must be. Accordingly, he rejects that democracy, as well as equality and liberty, are "criterial concepts that can be explicated through some neutral analysis that makes no assumption about their value or importance." Instead, he intends "to show why it is so important to understand that these are interpretative concepts."50

In that sense, Dworkin embarks himself in the quest for "A Better Program" by reaffirming: "We do better when we accept that the familiar concepts of political virtue are interpretive concepts." 51 In addition, in Is Democracy Possible Here? he insisted that democracy cannot be reduced to a procedural ideal as the majoritarian conception purports but to a substantive one as the partnership conception proclaims: 52

The majoritarian conception purports to be purely procedural and therefore independent of other dimensions of political morality; it allows us to say, as I indicated, that a decision is democratic even if it is very unjust. But the partnership conception does not make democracy independent of the rest of political morality; on that conception we

48 Ibidem, p. 348.

49 Idem: "intrinsically good about it".

50 Ibidem, p. 345.

51 Ibidem, p. 349.

52 Dworkin, Is Democracy Possible Here?..., supra note 14, p. 134. 
need a theory a theory of equal partnership to decide what is or is not a democratic decision, and we need to consult ideas about justice, equality, and liberty in order to construct such a theory. So on the partnership conception, democracy is a substantive, not a merely procedural, ideal.

Hence, he develops a substantive conception of community intertwined with democracy, equality and liberty: ${ }^{53}$

In such a community, the distribution of political power must reflect both these principles: the structure and decisions of government must acknowledge both people's equal importance and their personal responsibility. A conception of democracy is a conception of how that challenge is best met through political structures and practices. Because we aim to interpret our two principles as mutually supporting, not conflicting, we must try to develop conceptions of equality, liberty, and democracy that support one another as well.

Since he has already developed the conception of equality as "equality of resources" and "equal concern" at length in Sovereign Virtue ${ }^{54}$ and elsewhere, ever since the appearance of his book review of John Rawls' A Theory of Justice in 1973 and of Taking Rights Seriously in 1977,55 we will proceed directly to his development of the conception of liberty, which is - and has been- present at the heart of his overall argument for equality as part of a "Trojan horse" strategy. Actually, in Taking Rights Seriously, he advanced:56

The central concept of my argument will be the concept not of liberty but of equality. I presume that we all accept the fol-

53 Dworkin, Justice for Hedgehogs, supra note 1, pp. 349-350. Cfr. Dworkin, Ronald, "Liberal Community", Sovereign Virtue, supra note 13, pp. 211-236. (There is Spanish version: La comunidad liberal, trans. Claudia Montilla, Bogotá, Siglo del Hombre Editores, 1996).

54 Vid. Dworkin, Sovereign Virtue, supra note 13, pp.1-3, 6-7, 12-14, 122-123, and $139-141$.

55 Vid. Dworkin, Taking Rights Seriously, supra note 4, pp. 180-183 and pp. 272-278.

56 Ibidem, pp. 272-273. 
lowing postulates of political morality. Government must treat those whom it governs with concern, that is, as human beings who are capable of suffering and frustration, and with respect, that is, as human beings who are capable of forming and acting on intelligent conceptions of how their lives should be lived. Government must not only treat people with concern and respect, but with equal concern and respect. It must not distribute goods or opportunities unequally on the ground that some citizens are entitled to more because they are worthy of more concern. It must not constrain liberty on the ground that one citizen's conception of the good life of one group is nobler or superior to another's. These predicates taken together, state what might be called the liberal conception of equality; but it is a conception of equality, not of liberty as license...

In that sense, Dworkin recalls that liberty is an "interpretive concept" and that "there are not one but two interpretive concepts of liberty", which he traces to two essays making such claim: "Benjamin Constant's The Liberty of the Ancients and the Liberty of the Moderns, and Isaiah Berlin's Two Concepts of Liberty": 57

The argument they make in different ways seems plausible, and it has been very widely accepted among political philosophers and thoughtful lawyers... We must distinguish two very different questions. Both assume that government, at least of and by human beings, is inevitably coercive. The first asks: By whom —and with whom- should I be coerced? The second asks: How much should I be coerced?

A political theory calls for positive liberty if it insists, in response to the first question, that people must be permitted

57 Dworkin, Justice for Hedgehogs, supra note 1, pp. 364-365. (Emphasis is original and footnote is omitted.) Vid. Constant, Benjamin, "De la liberté des anciens comparée àcelle des modernes", in Collection Complète des Ouvrages, París, Béchet Libraire, 1820; and Berlin, Isaiah, "Two Concepts of Liberty", in Four Essays on Liberty, London, Oxford University Press, 1969, pp. 118-172. (Originally published: 1958.) Vid. also Flores, Imer B., "Los dos conceptos de libertad: ¿Competición o colaboración?”, in Sergio Sarmiento (coord.), Tercer Concurso de Ensayo "Caminos de la Libertad". Memorias, México, Grupo Salinas y Fundación Azteca, 2009, pp. 199-213. 
to play a role in their own coercive governance: that government must in some sense or another be self-government. A theory calls for negative liberty if it insists, in response to the second question, that people must be free of coercive government over some substantial range of their decisions and activities. Both these ideas —of positive and negative libertyare initially puzzling. How can coercive government by a group larger than a single person be self-government for everyone? If coercive government is legitimate at all, then how can we carve out some area of decision and activity that government has no right to regulate?

He later remembers that his second principle of dignity provides an answer to such questions: "People must be allowed responsibility for their own lives, and... that responsibility is compatible with governance by others only when certain conditions are met." And such conditions are:58

First, everyone must be permitted to participate in the right way in the collective decisions that make up his governance, and second, everyone must be left free from collective decision in matters that his personal responsibility demands he decide for himself. Because responsibility has those two dimensions, so does liberty. A theory of positive liberty stipulates what it means for people to participate in the right way. It offers, that is, a conception of self-government. A theory of negative liberty describes which choices must be exempt from collective decisions if personal responsibility is to be preserved.

In my opinion, Dworkin argues both for the compatibility between the two liberties and for the priority of the negative over the positive liberty. Accordingly, for him, in a democracy as a conception of self-government: (1) the people must be allowed personal responsibility for their own lives, and such responsibility is compatible with governance by others or political responsibility only when certain conditions are 
met; and (2) those conditions include certain choices that must be exempt from collective decision if personal responsibility is to be preserved and to be taken seriously. ${ }^{59}$

\section{COMmEnt to JEREMY WALDRON'S “A MAJORITY IN THE LIFEBOAT"}

In this section, we will reconsider not only the critical resistance produced by Waldron in his article "A Majority in the Lifeboat" to Dworkin's Justice for Hedgehogs and partnership conception of democracy but also the response provided by Dworkin himself. However, since it may appear insufficient we will try to present an alternative -or complementary - riposte in order to meet Waldron's challenge.

\section{Waldron's Resistance}

Jeremy Waldron - right from the start of his critical essay- affirms: "[Dworkin] is not a fan of the principle of majority-decision" 60 and "[H]e says he believes in democracy, but he is not enthusiastic about any version of democracy that is defined by the use of majority-decision." 61 The question seems to be quite straight: How come? How can someone be committed to democracy and not be com-

59 This two-fold argument is necessary to respond to Waldron's challenge. Vid. infra note 95 (and accompanying text).

60 Waldron, Jeremy, "A Majority in the Lifeboat", in "Symposium...", supra note 1, p. 1043. Additionally, Waldron advances in footnote 1: "I will not follow Dworkin in characterizing the relevant principle as "majority rule," for reasons stated by Hannah Arendt: "Only where the majority, after the decision has been taken, proceeds to liquidate politically... the opposing minority, does the technical device of majority decision degenerate into majority rule." "Id., footnote 1 (the reference is omitted).

My gut feeling is that Dworkin's use of the expression "majority rule" is not limited to such characterization of a corrupt, degenerated or impure form of "majority decision", and so we can assume that "majority decision", "majority rule", and even "majority vote", can be used interchangeably.

61 Waldron, “A Majority in the Lifeboat", supra note 60, pp. 1043-1044. 
mitted to majority-decision? The answer can also be straight away: majority-decision is neither a necessary nor sufficient condition for democracy. Actually, Waldron does grant it: "Of course, majority-decision is not necessarily democratic." 62 However, since Dworkin has been advocating throughout this book and most of his work for an interpretive (or anti-criterialist) approach, his answer has to be slightly different: democracy cannot be reduced to any criteria and much less to the majority-decision criterion.

In addition, Waldron asserts "Dworkin believes that strong judicial review is compatible with democracy, but of course, this is not because judges use majority-decision."63 The question seems to be again: How come? How can someone, on the one hand, be committed to democracy and strong judicial review and, on the other hand, not be committed to majority-decision, but accept its exercise or use. In that sense, he insists by recalling: "It has been more than twenty years since I began challenging defenders of judicial review to explain the use of the majority-principle by courts exercising "counter-majoritarian" judicial review; I have long since given up any expectation of an honorable answer."64 Providing such "honorable answer" is the main aim of Dworkin's response and of our own alternative -or complementary - riposte. ${ }^{65}$

In his paper, Waldron comes to terms with Dworkin's "hoary philosophical example" considering that it is intended to be "a knockdown argument against the view that majority decision is fair." 66 In addition, he suggests, on one side, hesitantly in a footnote: "Perhaps it has something (a little) in common with Fuller's example of the explorers trapped in a cave who drew lots to eat one of their num-

62 Ibidem, p. 1044.

63 Idem.

64 Idem.

65 Vid. infra, IV. 2. \& 3.

66 Ibidem, p. 1045. 
ber."67 On the other, decisively both in the text: "I suppose it owes something to United States $v$. Holmes - a well-known case from 1842 in which fourteen passengers were thrown overboard from a lifeboat in danger of sinking"; 68 and, in a footnote: "I suppose one might also cite $R$. $v$. Dudley \& Stevens... (finding crew of shipwreck guilty of murder where they killed and ate their cabin boy in order to survive). Dworkin's casual reference to a "cabin boy"... hints in this direction". 69

Waldron is absolutely right in the connection between both Holmes and Dudley \& Stevens with Dworkin's example and -despite his hesitation- with Fuller's explorers. ${ }^{70}$ There are at least two grounds for the later claim: 1) the temporary edition of The Problems of Jurisprudence by Lon L. Fuller, where "The Case of the Speluncean Explorers" appears for the first time in printed form includes a "Note" by Fuller himself: "This case was suggested by Queen v. Dudley and Stephens...; and United States v. Holmes...";71 and 2) the Spanish translation of "The Case of the Speluncean Explorers" incorporates a "Preliminary Note" by Genaro R. Carrió: "The facts of this imaginary case are not totally imaginary. Fuller affirms that the facts were suggested to him by Queen $v$. Dudley and Stephens... and United States $v$. Holmes...". ${ }^{72}$

Anyway, Waldron proceeds later not only to analyze and criticize the discussion of methods of choice found in

67 Ibidem, p. 1045, footnote 12 (the reference is omitted).

68 Ibidem, p. 1045.

69 Ibidem, pp. 1045-1046, footnote 13 (the reference is omitted).

70 Vid. Fuller, Lon L., "The Case of the Speluncean Explorers", 62 Harvard Law Review, 616 (1949).

71 Vid. Fuller, Lon L. The Problems of Jurisprudence, Brooklyn, The Foundation Press, 1949, p. 27.

72 Vid. Carrió, Genaro R., "Nota preliminar", in Fuller, Lon L., El caso de los exploradores de cavernas, trans. Genaro R. Carrió, Buenos Aires, Abeledo-Perrot, 1961, p. 5: "Los hechos de este caso imaginario no son totalmente imaginarios. Fuller afirma que le fueron sugeridos por Queen vs. Dudley and Stephens (L.R. 14 Q. B. Div. 273; 1884) y por United States vs. Holmes (1 Wall. 1; 1842).” 
Holmes, ${ }^{73}$ but also to scrutinize: "What is Dworkin's example supposed to show?". ${ }^{74}$ For that purpose he ranks four possible conclusions (ranked according to him from strongest to weakest): ${ }^{75}$

(1) It is silly to think that majority-decision is intrinsically fair or intrinsically valuable.

(2) It is not the case that majority-decision is ever intrinsically fair or intrinsically valuable.

(3) Majority-decision is not intrinsically fair or intrinsically valuable in all circumstances.

(4) Majority-decision is not intrinsically fair or intrinsically valuable in circumstances just like the life boat example.

And, finally, correlates them to Dworkin's main conclusion: 76

(5) A definition that ties the term firmly to majority-decision is an unhelpful misconception of democracy.

In short, Waldron is quite skeptical that the lifeboat example can either establish anything strong as conclusions (1) and (2), which might lay a foundation for (5);77 or get us to conclusions (3) and (4), and lay a foundation for (5). ${ }^{78}$ Considering that justice has not been done to the lifeboat example, he tries one (or several) more pass(es). For that

73 Waldron, “A Majority in the Lifeboat", supra note 60, pp. 1046-1047.

74 Ibidem, p. 1048.

75 Ibidem, pp. 1048-1049.

76 Ibidem, p. 1049.

77 Idem: "[I]f the lifeboat example established conclusion (1) or conclusion (2), it might conceivably lay a foundation for (5), i.e., for this broader claim about how to think and how not think about democracy. But it is not clear how the lifeboat example can establish anything that strong."

78 Ibidem, p. 1050: "But it is not at all clear that we can extrapolate from the inappropriateness of using majority-decision in the lifeboat to the inappropriateness of associating democracy with, say, the democratic of representatives or the democratic basis of legislation. I think is arguable that the lifeboat example gets us to conclusion (3) or (4). But there remains a huge gulf fixed between those conclusions and the further conclusion (5), which is what Dworkin is really interested in." 
purpose, he distinguishes, first, between "choices about particulars and choices about general issues of policy and principle", ${ }^{79}$ and, later, following Dworkin, between "personal" and "external" preferences. ${ }^{80}$ On the one hand, he brings to mind: "But at most, Dworkin has discredited majority-decision as a procedure for making particular life and death choices of for [sic] individuals and has (tendentiously) discredited majority-decision in the choice of the proper ambit of the majority-principle itself. Since these uses of the majority-principle are so marginal, it is hard to see that they get us anywhere remotely near to (5)." ${ }^{81}$ And, similarly, on the other hand, he calls to mind: 82

[T] he external preferences point... was not supposed to show the inappropriateness of majority-decision making (or utilitarian calculation) in general. It was supposed to show its inappropriateness in a limited range of cases. And that is what the lifeboat example might illustrate: It offers us an instance of a strange sort of case in which any enthusiasm we might have for majority-decision might be qualified (for certain odds kinds of case). That's conclusion (4) above. But that won't get us to (5); it doesn't establish the inappropriateness of majoritarianism in general, let alone the "silliness" of associating it with democracy.

Finally, Waldron, on one side, regrets that Dworkin "did not take the trouble to relate the lifeboat example (and what he draws from it) to the broader considerations of political equality that are widely believed to give majority-principle whatever plausibility it has as a principle of political decision." 83 And, on the other, reckons "The lifeboat example adds nothing to that discussion... I fear that its con-

80 Ibidem, pp. 1053-1054.

81 Ibidem, p. 1052.

82 Ibidem, p. 1054.

83 Idem. 
stant introduction into the discussion of democracy by Dworkin and others is little more than a distraction." 84

\section{Dworkin's Response}

Firstly, Dworkin clarifies that his main "point" is not, as Waldron says, to reject a definition of democracy that "ties the term firmly to majority-decision" but "rather to reject any definition that "ties" democracy "firmly" to any specification." 85 Especially, since that will amount "to treat democracy as criterial", when he wants to treat it as an "interpretive concept" and the "majoritarian conception is certainly an eligible one, even though... unsuccessful." 86

Secondly, Dworkin explains that he intends to make with the lifeboat example "a very limited and highly circumscribed point: only that the majoritarian decision principle is not, as he [i.e. Waldron] has claimed it to be, a general principle of fairness independent of context - that is, "intrinsically" fair process." $87 \mathrm{He}$ further elucidates that it is not a "knock-down" argument against a majoritarian conception of democracy: "This is most certainly not an argument, however, that majority rule is never a fair method of decision. On the contrary, I insist that it is appropriate in politics when conditions of legitimacy are."88

In a summary, Dworkin provides two reasons to reject the majoritarian conception of democracy: 1) the concept of democracy is interpretive and hence is not firmly tied to any criteria or specification, much less to the majority-decision that is neither a necessary nor a sufficient condition; and, 2) the majority principle is not an intrinsically fair process, but that does not mean that is never a fair method of decision.

84 Ibidem, p. 1057.

85 Dworkin, Ronald, "Response", in "Symposium...", supra note 1, p. 1084.

86 Ibidem, p. 1085.

87 Idem.

88 Idem. 
Thirdly, Dworkin attempts to provide "an honorable answer" to the question that Waldron has been asking for twenty years: "Why, if majority rule is not intrinsically fair, is it appropriate on final appellate courts like the Supreme Court, which decides many very important cases by a 5-4 vote?". ${ }^{89}$ A part of his response was already there: although the majority principle is not an intrinsically fair process, it does not mean that it is never a fair method of decision. Actually, he tried to justify the appropriateness of majority rule as a check on majoritarian procedure and insisted by repeating: 90

The choice among checks on majoritarian procedures must of course depend on which options are available. Judicial review is an available option for checking legislative and executive decisions. It is also an available option for checking judicial review itself through a hierarchical system of appellate courts. But of course judicial review is not available to check the decision of the highest appellate court; if it were the court would not be the highest.

This response echoes the one provide in the "Introduction" to Freedom's Law:91

If we reject the majoritarian premise, we need a different, better account of the value and point of democracy... which I call the constitutional conception of democracy...It denies that it is a defining goal of democracy that collective decisions always or normally be those that a majority or plurality of citizens would favor if fully informed and rational. It takes the defining aim of democracy to be a different one: that collective decisions be made by political institutions whose structure, composition, and practices treat all members of the community, as individuals, with equal concern and respect. This alternate account of the aim of democracy, it is true, demands much the same structure of government as

89 Ibidem, p. 1086.

90 Idem.

91 Dworkin, "Introduction...", supra note 24, p. 17. 
the majoritarian premise does. It requires that day-to-day political decisions be made by officials who have been chosen in popular elections. But the constitutional conception requires these majoritarian procedures out of a concern for the equal status of citizens, and not out of any commitment to the goals of majority rule. So it offers no reason why some nonmajoritarian procedure should not be employed on special occasions when this would better protect or enhance the equal status that it declares to be the essence of democracy, and it does not accept that these exceptions are a cause of moral regret.

The constitutional conception of democracy, in short, takes the following attitude to majoritarian government. Democracy means government subject to conditions... of equal status for all citizens. When majoritarian institutions provide and respect the democratic conditions, then the verdicts of these institutions should be accepted by everyone for that reason. But when they do not, or when their provision or respect is defective, there can be no objection, in the name of democracy, to other procedures that protect and respect them better.

In addition, he reintroduces -following Waldron's suggestive critique - a distinction "between people's preferences about their own lives and their preferences about what should happen to other people", i.e. between personal (or internal) and (political or) external preferences, "to explain why a majoritarian process with no judicial or other check is not well suited to produce unbiased results."92 $\mathrm{He}$ further recognizes: "I could only use the distinction in this context to suggest that majoritarian politics should be qualified not abandoned" and to conclude: "Majoritarian procedures are appropriate -indeed sometimes necessary- in circumstances when they are fair. Judicial review is among the arrangements that might improve their fairness though,

92 Dworkin, "Response", in "Symposium...", supra note 1, p. 1086. Dworkin introduced the distinction in Taking Rights Seriously, supra note 4, pp. 234-238. 
as I emphasize, it is not the only such arrangement."93 In sum, Dworkin's response succeeded to indicate that majority decisions, including judicial review, are appropriate in circumstances when they are fair, but failed to insinuate when it was the case.

\section{Alternative - or Complementary - Riposte}

Since Dworkin's response to Waldron's resistance was more or less the same in the oral reply that preceded the written one, nothing suggests that he will be completely persuaded or pleased by it; 94 and, thus, I intend to present an alternative —or complementary - riposte.

First and foremost, let me intimate that Dworkin in his response to Waldron did answer fully to two questions but felt short from answering to a third: Are majority decisions appropriate? Yes, majority decisions are appropriate... When? ...in circumstances when they are fair. But did not respond to: When are they fair? I guess at this point his answer must have been something like: Majority decisions are appropriate in circumstances when they are fair; they can only be fair when certain conditions are met; and such conditions incorporate certain choices that must be exempt from collective decision. 95 But, again, which are the choices that must be exempted from majority decision? Providing an "honorable answer" to Waldron's challenge by responding to this last question is the aim of the following riposte.

Waldron is right in saying that Dworkin is not a fan of the principle of "majority decision", "majority rule", and "majority vote", because for him the principle is not intrin-

93 Dworkin, "Response", in "Symposium...", supra note 1, p. 1087.

94 Ibidem, p. 1086: "I offered what I thought to be the obvious answer at the conference this issue reports, but since Waldron repeats his claim in his written article, he must have found my reply dishonorable. I am shameless enough to repeat it."

My hunch, since I was present at the conference, is that at this point Dworkin and Waldron seem to be talking past each other.

95 Vid. supra note 59 (and accompanying text). 
sically fair or valuable - at least not always or in all circumstances. In sum, he doesn't believe that "when people in a society disagree about some decision (among two or more options) the fairest way to proceed is for them all to vote, for the votes to be counted, and for the option to be chosen which attracts the greatest number of supporters."96 However, Waldron is wrong in stating that Dworkin does not confer "any legitimacy upon the option that the majority supports", 97 as we have seen in his response to him, it is not the case that majority decision is never fair or legitimate, but at least not always or in all circumstances.

Curiously, Waldron's "conclusion" that best characterizes Dworkin's claim is “(3) Majority-decision is not intrinsically fair or intrinsically valuable in all circumstances." And from there he establishes a foundation for a broader claim, which constitutes his main argument: “(5) A definition that ties the term [i.e. democracy] firmly to majority-decision is an unhelpful misconception of democracy." Although (1) and (2) might lay a foundation for (5), those conclusions, besides being too strong, rule out any legitimate use for a majority decision, because it is either silly to think it is intrinsically fair or valuable or that it is never intrinsically fair or valuable, but as Waldron points out Dworkin champions the use of majority decision by courts exercising judicial review. Certainly, (4) besides being too weak, it is too marginal -by focusing in circumstances such as the lifeboat example - to lay a foundation for (5). ${ }^{98}$

If a "majority decision" is not intrinsically fair or intrinsically valuable in all circumstances (3), the concept of "democracy" cannot be tied to it (5), unless willing to admit that "democracy" is not intrinsically fair or valuable. To the contrary, Dworkin believes that "democracy" is intrinsically fair or valuable; and, hence, has to untie "democracy" from "majority decision", which is not intrinsically fair or valu-

\footnotetext{
96 Waldron, "A Majority in the Lifeboat", supra note 60, p. 1043.

97 Idem.

98 Ibidem, pp. 1048-1049.
} 
able - at least not always or in all circumstances - leading to the distinction between the "majoritarian or statistical conception", which ties democracy to majority decision, and the "partnership conception", which unties democracy from majority decision. 99

Whereas the "majoritarian or statistical conception" considers that the majority decision is a necessary - and even sufficient- condition of a democracy, the "partnership conception" considers that the majority decision is a mere contingency neither necessary nor sufficient. Therefore, it is possible both to reject in a democracy the use of a majority decision per default and to accept its use in some cases, but neither in all circumstances nor always, including the use of majority decision by courts exercising judicial review, which is consistent with conclusions (3) and (5).

Assuming that majority decisions are appropriate in circumstances when they are fair; that they can only be fair when certain conditions are met; and that such conditions integrate certain choices that must be exempt from collective decision. The only question remaining to be answer is: which are the choices that must be exempted from majority decision? Actually, Waldron's distinction between "choices about particulars and choices about general issues of policy and principle"100 is helpful to distinguish between general choices or decisions proper to a legislative body, which are more political than technical, and particular choices or decisions proper to a judiciary - or even to a regulatory agency, which are more technical than political, but unhelpful to determine which are the choices that must be exempted from majority decision because their illegitimacy.

My hunch is that we need to introduce a further distinction between impartial and partial choices or decisions; ${ }^{101}$

99 Dworkin, Justice for Hedgehogs, supra note 1, p. 5.

100 Waldron, "A Majority in the Lifeboat", supra note 60, pp. 1050-1052.

101 I am assuming that the distinction between objective and subjective criteria is already settled in favor of objective choices or decisions only. Vid. Flores, Imer B., "Legisprudence: The Role and Rationality of Legislators - vis-à-vis Judges- to- 
that is, between choices or decisions, on the one hand, made by someone who is not a party (impartial) and can be more or less objective; and, on the other hand, taken by someone who is a party (partial) and can be more or less subjective and even biased. In a democracy, the former - impartial choices or decisions - can be made by a majority decision and the latter - partial choices or decisionscannot be taken by a majority decision. In that sense, it seems clear to me that the justices of a Supreme Court can decide about the life or death of a criminal by a majority vote because they are making an impartial decision (they are not a party), but those same justices of the Supreme Court cannot decide about the life or death of one of the justices by a majority vote (having to sacrifice one life to save the rest) because they will be taking a partial decision (they are a party). Suppose, following Fuller's speluncean explorers case, that they are trapped in a cave after a field trip or in the main chamber of the Court after an earthquake, or, alternately, following Dworkin's example, that they are found in a lifeboat example situation after a cruise. In both cases, a lottery or drawing lots will be a much fairer or legitimate - and impartial - way of deciding which life will be sacrificed for the sake of saving the rest.

Consider Dworkin's (democratic) lifeboat example again, ${ }^{102}$ he rejects a majority decision as democratic since everyone is a party or a partner in the lifeboat and sacrificing one will amount for a partial choice or decision being impose over the life of one party or partner, which will not be treated with equal concern and respect. On the contrary, he accepts a decision by lottery, i.e. a non-majority decision, which grants to the life of each party or partner an equal concern and respect. In short, Dworkin is going to re-

wards the Realization of Justice”, Mexican Law Review, New Series, Vol. 1, No. 2, 2009, pp. 91-110; and , especially, pp. 94-100.

102 Let me suggest that Dworkin's lifeboat is a democracy, whereas in the Holmes case, quoted by Waldron the lifeboat is not a democracy, i.e. an autocracy, where the captain makes or takes a decision regardless of the interest of the passengers. Vid. supra note 30 . 
ject any majoritarian decision which does not show equal concern or respect not only for the life but also for the rights of the parties or partners in a democracy, including minorities, by failing to be impartial, and is willing to accept those that are impartial and do treat everyone with equal concern and respect.

Finally, regarding Waldron's unmet “challenge to defenders of judicial review to explain the use of the majority principle by courts exercising "counter-majoritarian" judicial review", I expect to have provided - or at least suggested- by introducing the distinction between partial and impartial choices or decisions an honorable answer. I guess the apparent paradox is that the courts use the majority-decision as a counter-majoritarian device, but I do not think it is really counter-majoritarian and much less counter-democratic and not even counter-representative, but merely counter-legislative or counter-executive, in the sense of contrary to a legislative or executive decision which is overruled, for failing to be impartial, objective and/or according to law.

Additionally, I will like briefly to point out a further justification for allowing a court to make or take their decisions with a majority vote. Clause 40 of the Magna Carta Libertatus reads as follow: "Nulli vendemus, nulli negabimus, aut differemus rectum aut justiciam", i.e. "To no one will we sell, to no one will we refuse or delay, right or justice." Since the reason one goes to court is to get justice, refusing or delaying to make a decision will amount to an injustice and as such to something illegitimate. In short, "justice delayed is justice denied". And so, if a court in order not to delay or deny justice has to take a decision by a majority vote it will, on the contrary, be legitimate.

\section{Conclusion: TAKIng Ronald Dworkin SERIOUsly}

To conclude I will like to insist on the importance of taking Ronald Dworkin seriously. His overall thesis, as he recognizes, is unpopular now: "[the foxes have] ruled the roost 
in academic and literary philosophy for many decades" and "[the h]edgehogs seem naïve or charlatans, perhaps even dangerous." 103 Moreover, as he clarified in a Lecture - titled "From Justice in Robes to Justice for Hedgehogs"- delivered after being awarded the Héctor Fix-Zamudio International Award at the Legal Research Institute of UNAM in Mexico City back in November 23, 2006:104

[T] he titles [of Justice in Robes, i.e. a book already written and published earlier that year, and Justice for Hedgehogs, i.e. a book in which he was working at that time] are meant to convey this, that we understand law, that we understand the role that justice plays in law, only when we understand law not in isolation from the rest of human value, but as part of a largest scheme of justice, using Isaiah Berlin's idea: justice for hedgehogs, not for foxes. And it's part of my argument that interpretation is, as it dominates in my view legal reasoning, a distinct kind of intellectual activity but also has its presence across the whole domain of interpretation. So then if we want to understand interpretation as a legal activity, we have to think about artistic interpretation, historical interpretation, biblical hermeneutics, [and] literary study. And my argument in Justice for Hedgehogs... is that we understand interpretation as a distinct intellectual activity by accepting that in interpretation, across all these domains, the purpose of the activity is part of the test of truth.

103 Dworkin, Justice for Hedgehogs, supra note 1, p. 2. For the depiction of a hedgehog applied to Madame Michel, one of Barbery's characters, but equally applicable mutatis mutando to Dworkin, vid. Barbery, The Elegance of the Hedgehog, supra note 42, p. 143: "Madame Michel has the elegance of the hedgehog: on the outside, she's covered in quills, a real fortress, but my gut feeling is that on the inside, she has the same simple refinement as the hedgehog: a deceptively indolent little creature, fiercely solitary —and terribly elegant."

104 Dworkin, Ronald, "From Justice in Robes to Justice for Hedgehogs" (manuscript on file with Problema). 